\title{
OBITUARY
}

\section{SIR RONALD SYME}

Sir Ronald Syme, a foundation member of the Council of the Institute and a Vice President since 1952, died on 4 September 1989 at the age of 86 . Since the publication of his first book, The Roman Revolution, in 1939, he was recognised as the outstanding Roman historian of his generation. Full and proper tribute to his immense achievements as a scholar and a writer belongs elsewhere, but it is fitting to draw attention to his contribution to our knowledge of Roman Asia Minor. Three masterly papers from the 1930s, "Galatia and Pamphylia under Augustus", Klio 27 (1934), 122-48, misguidedly omitted from his collected Roman Papers, "Pamphylia from Augustus to Vespasian". Roman Papers I, 42-6, and "Observations on the Province of Cilicia", in Anatolian Studies presented to W. H. Buckler (1939), reprinted in Roman Papers I, 120 48, provide a detailed framework for understanding the early Roman administration of central Anatolia. During the war he served as Press Attaché first in Belgrade and then in Istanbul, where he was also Professor of Classical Philology from 1942-45. Tantalising glimpses of a first hand knowledge of Turkey emerge in the footnotes of his later work, but Syme himself revealed little directly about his activities during this period. As Camden Professor of Roman History at Oxford from 1949 to 1970 he wrote little on Asia Minor, but during his astonishingly productive retirement he published a stream of papers. Some elucidated the careers and activities of Roman governors who had administered the Anatolian provinces, such as L. Calpurnius Piso, L. Caesennius Sospes, M. Acilius Glabrio, L. Flavius Arrianus, L. Antistius Rusticus, P. Calvisius Ruso Frontinus, and C. Rutilius Gallicus (Roman Papers III, 869-84, 1043-61, 1316-36; IV 21-49, 278-94, 397-417; V, 514-20). Others reflect the passion of his early years for historical geography and even ethnography: "Tigranocerta: a problem misconceived" was written for the Institute's own colloquium on Eastern Frontier Studies held in Swansea in 1981 (Roman Papers IV, 245-5I); "Isauria in Pliny", was a contribution to Anatolian Studies in 1986 (reprinted in Roman Papers $\mathrm{V}, 661-7)$, and a longer study, "Isaura and the Isauri. Some Problems" emerged soon afterwards in Sociétés urbaines, sociétés rurales dans l'Asie Mineure et la Syrie hellénistiques et romaines, Strasburg 1987, 131-47.

In all his work style, vision and understanding of human nature were matched by a fantastic control of historical detail, which derived from acute observation and a flawless memory. One example may serve to illustrate the point. During the 1930s a minor controversy surfaced in the scholarly literature about the shape and extent of Suğla Göl in Isauria (summarised by A. S. Hall, Anat. Studs. 18 (1968), 57 n. 2 with an important additional comment in Anat. Studs. 21 (1971), 125 n. 3). Syme, in his last paper on Isauria added a single footnote to the discussion (p. $143 \mathrm{n} .105$ ): "When I glimpsed Trogitis from the air in November of 1949, it was kidneyshaped, the south-eastern portion being dry". A photograph taken by the Challenger Space Shuttle in a pass over SW Anatolia may stand as arbiter; the lake is indeed kidney-shaped.

S. Mitchell 